\title{
Impact of an Interprofessional Education Quality of Life Forum on Students' Perceptions and Commitment to Addressing Local Health Disparities and the Social Determinants of Health
}

Jamie Bayliss

Mount St. Joseph University, jamie.bayliss@msj.edu

Erin Hofmeyer

Mount St. Joseph University, erin.hofmeyer@msj.edu

BC Charles-Liscombe

Mount St. Joseph University, bc.charles-liscombe@msj.edu

Kristin Clephane

Mount St. Joseph University, Kristin.clephane@msj.edu

Sandra Matthias

Mount St. Joseph University, sandra.matthias@msj.edu

See next page for additional authors

Follow this and additional works at: https://nsuworks.nova.edu/ijahsp

Part of the Interprofessional Education Commons, and the Scholarship of Teaching and Learning Commons

\section{Recommended Citation}

Bayliss J, Hofmeyer E, Charles-Liscombe B, Clephane K, Matthias S, Glankler D, et al. Impact of an Interprofessional Education Quality of Life Forum on Students' Perceptions and Commitment to Addressing Local Health Disparities and the Social Determinants of Health. The Internet Journal of Allied Health Sciences and Practice. 2020 Jan 01;18(2), Article 7.

This Manuscript is brought to you for free and open access by the College of Health Care Sciences at NSUWorks. It has been accepted for inclusion in Internet Journal of Allied Health Sciences and Practice by an authorized editor of NSUWorks. For more information, please contact nsuworks@nova.edu. 


\title{
Impact of an Interprofessional Education Quality of Life Forum on Students' Perceptions and Commitment to Addressing Local Health Disparities and the Social Determinants of Health
}

\begin{abstract}
ABSTRACT

Purpose: Healthcare providers and educational programs share a challenge where limited resources make interprofessional education (IPE) and collaboration difficult. The purpose of this research was to investigate the impact of IPE, specifically The Greater Cincinnati Quality of Life Forum within the School of Health Science at Mount St. Joseph University, on students' perceptions of communication skills, collaboration, and values of interprofessional practice as they relate to emergent topics within the community and healthcare. Methods: Consenting participants completed an electronic survey with five reflection questions. Qualitative assessment included analysis of text for emergent themes. Results: Four themes evolved impacting future practice: consciousness, roles and responsibilities, professional values and ethics, and skepticism of the IPE activity benefit. Analysis of data also revealed three learnerreadiness categories: desire to know, desire to act, and questioning value and validity. Conclusion \& Recommendations: This IPE activity aimed to integrate holistic patient care approaches within a supportive interprofessional team. Educators ought to consider alignment of IPE activities to the learner audience for better integration of the process. Future research should also include longitudinal assessment of students' development through IPE activities.
\end{abstract}

\section{Author Bio(s)}

Jamie Bayliss, PT, MPT, DHSc, is an Assistant Professor and Director of Clinical Education in the Department of Physical Therapy at Mount St. Joseph University in Cincinnati, Ohio.

Erin Hofmeyer, PT, DPT is an Instructor and Assistant Director of Clinical Education in the Department of Physical Therapy at Mount St. Joseph University in Cincinnati, Ohio.

BC Charles-Liscombe, EdD, LAT, ATC is the Chair and an Associate Professor in the Department of Athletic Training at Mount St. Joseph University in Cincinnati, Ohio.

Kristin Clephane, DNP, RN, CNP is the RN-BSN/MSN Program Director and an Assistant Professor in the Department of Nursing at Mount St. Joseph University in Cincinnati, Ohio.

Sandra Matthias, MSN, RN is an Assistant Professor in the Department of Nursing at Mount St. Joseph University in Cincinnati, Ohio.

Donna Glankler, DNP, RN, CNE is an Assistant Professor in the Department of Nursing at Mount St. Joseph University in Cincinnati, Ohio.

Nicole Harshbarger, MS, AT, ATC is an Assistant Athletic Trainer at Brevard College.

\section{Authors}

Jamie Bayliss, Erin Hofmeyer, BC Charles-Liscombe, Kristin Clephane, Sandra Matthias, Donna Glankler, and Nicole Harshbarger 


\title{
TIAHSP \\ The Internet Joumnal of Allied Health Sciences and Practice \\ Dedicated to allied health professional practice and education
}

Vol. 18 No. 2 ISSN 1540-580X

\section{Impact of an Interprofessional Education Quality of Life Forum on Students' Perceptions and Commitment to Addressing Local Health Disparities and the Social Determinants of Health}

\author{
Jamie Bayliss \\ Erin Hofmeyer \\ BC Charles-Liscombe \\ Kristin Clephane \\ Sandra Matthias \\ Donna Glanker \\ Nicole Harshbarger \\ Mount St. Joseph University \\ United States
}

\begin{abstract}
Purpose: Healthcare providers and educational programs share a challenge where limited resources make interprofessional education (IPE) and collaboration difficult. The purpose of this research was to investigate the impact of IPE, specifically The Greater Cincinnati Quality of Life Forum within the School of Health Science at Mount St. Joseph University, on students' perceptions of communication skills, collaboration, and values of interprofessional practice as they relate to emergent topics within the community and healthcare. Methods: Consenting participants completed an electronic survey with five reflection questions. Qualitative assessment included analysis of text for emergent themes. Results: Four themes evolved impacting future practice: consciousness, roles and responsibilities, professional values and ethics, and skepticism of the IPE activity benefit. Analysis of data also revealed three learner-readiness categories: desire to know, desire to act, and questioning value and validity. Conclusion \& Recommendations: This IPE activity aimed to integrate holistic patient care approaches within a supportive interprofessional team. Educators ought to consider alignment of IPE activities to the learner audience for better integration of the process. Future research should also include longitudinal assessment of students' development through IPE activities.
\end{abstract}

Keywords: interprofessional education, social determinants of health, interprofessional collaboration 


\section{INTRODUCTION}

As educators of future healthcare professionals, it is the responsibility of the academic programs to cultivate interprofessional education (IPE) experiences prior to clinical education and matriculation into the workforce. Academicians are challenged by implementing successful IPE initiatives because of lack of resources (financial and infrastructure), buy-in from faculty, and administration, time, and curricula. ${ }^{1}$ As healthcare providers, it is essential that we know how to function not only autonomously, but also as a contributing member of the interprofessional team while meeting the needs of society. Prevalent issues currently impacting society are the Social Determinants of Health $(\mathrm{SDoH})$ and Health Disparities $(\mathrm{HD}) .{ }^{2}$ These societal concerns can be varied and complex. By placing the patient first and addressing their needs holistically, as recommended by the World Health Organization's (WHO) International Classification Framework (ICF), the healthcare provider can prioritize and identify additional resources for optimal patient care. ${ }^{3}$

Oftentimes, the demands on time, productivity, resources, and other personal factors preclude healthcare providers from effectively contributing to the interprofessional team. ${ }^{4}$ Mitigating factors toward effective teaming include one's own personal biases, values, and ethics. One's knowledge of their professional role, as well as other healthcare professions roles, also affects the ability to successfully team. Communication within the healthcare team is another ongoing paradox which requires intentional practice to become a contributing member of the team and ultimately achieve the Triple Aim of Healthcare, including improved population health, improved experience of care, and reduced cost of care. ${ }^{5}$

Because of these challenges, it is a requirement of several health professions' accrediting bodies that students participate in IPE, thereby preparing the students to provide comprehensive patient-centered care. ${ }^{6}$ Healthcare providers and the academic programs share a common challenge where limited resources make IPE and interprofessional collaboration (IPC) difficult. In response to these concerns, the School of Health Sciences at Mount St. Joseph University (the Mount) developed an annual Quality of Life Forum (Forum) to not only meet accreditation standards, but to ensure student engagement related to current societal issues. This event sought to use IPE pedagogy to educate the students on the SDoH and HD within the Greater Cincinnati community.

\section{Current Trends in Interprofessional Education}

A Bridge to Quality, a consensus study report from 2003, recommends a patient-centered approach to care within healthcare curricula. ${ }^{7}$ The Interprofessional Education Collaborative (IPEC) core competencies (Values/Ethics, Roles/Responsibilities, Interprofessional Communication, and Teams and Teamwork) also emphasize that healthcare profession curricula should incorporate IPE. ${ }^{10}$ The WHO framework advocates that IPE should be an essential component to curricula when educating students on the prevalence of societal issues such as the $\mathrm{SDoH}$; however, a gap continues to exist in the evidence demonstrating a direct link between IPE, IP practice, and improved patient outcomes.

An essential component of IPE is for students to understand their own healthcare professional role and the roles of other members of the healthcare team. ${ }^{8}$ Evidence indicates that students benefit from IPE as it aids in clarification of healthcare roles. ${ }^{9}$ Interprofessional education needs to be well designed, be embedded, and include the integration of IPEC core competencies. ${ }^{10}$ Academic programs should integrate experiences early and intentionally throughout curricula. ${ }^{11}$ The format of IPE may include merging classes, simulation, community-based initiatives, and E-learning. Regardless of delivery method, educational activity structure should allow for reflection and interaction to cultivate a positive student experience. ${ }^{12}$ In order for students to feel as if the activity has importance toward their learning experience, a graded assignment that is aligned with current research is necessary. ${ }^{13}$ Interprofessional assignments that are not graded are considered "busy work."13

\section{Purpose}

Healthcare delivery occurs in the context of the patient's community. In order to effectively implement the ICF model, a framework measuring health and disability at both individual and population levels, students must understand the characteristics of the community where they will practice. ${ }^{3}$ In an effort to foster the emerging themes within IPE literature, an annual forum whereby students from different academic programs, across a liberal arts campus, participated in a case-based discussion on addressing factors associated with quality of life and health disparities as they are affected by personal values and biases.

The purpose of this research was to investigate the impact of IPE, specifically The Greater Cincinnati Quality of Life Forum within the School of Health Science at Mount St. Joseph University, on students' perceptions of communication skills, collaboration, and values of IP practice as they relate to emergent topics within the community and healthcare. The aim of this qualitative study was to assess the effectiveness of the event on student learning, what impact the forum had on their perceptions and interactions with the community, and how they can take their experience with the forum to be a 'change' leader through the use of a survey. The focus for the 2018 Forum was on SDoH and HD. 


\section{METHODS}

\section{Research Setting}

The Greater Cincinnati Quality of Life Forum (The Forum) was held at Mount St. Joseph University (the Mount) in Spring, 2018. Located in the southwest region of Ohio, the Greater Cincinnati/Tri-State region borders Indiana and Kentucky along the Ohio River. The region has both a German immigrant history with close ties to Appalachia while also being one of the first stops on the Underground Railroad. The region has a concentrated disadvantage with significant income inequality and racial segregation across urban and rural regions. Cincinnati ranks $6^{\text {th }}$ in the nation with 53 percent of children living in poverty. ${ }^{14}$ There is a critical need in the community to develop the knowledge and skills to collaborate and address the factors impeding Cincinnati's collective success.

As a mission-driven Catholic institution, all programs at the Mount integrate the liberal arts tradition within professional curricula that emphasize values, integrity, and social responsibility. The School of Health Sciences includes the following departments: Athletic Training, Nursing, Physical Therapy, and Physician Assistant Studies. The School has incorporated instructional strategies (case study analysis, high fidelity and low-fidelity simulation, and partnered projects) with interprofessional teams of students. Most recently, the School and the Center for Ethical Leadership partnered to sponsor The 2018 Greater Cincinnati Quality of Life Forum.

\section{Participant Characteristics}

Students and faculty from the School of Health Sciences comprised 78 percent of the Forum attendees $(N=200)$. Seventeen percent of the attendees were from departments outside of the School of Health Sciences $(\mathrm{N}=44)$. Community members from health-related agencies and healthcare providers also attended the event $(\mathrm{N}=11 ; 5 \%)$. Refer to Table 1 for the specific Forum attendee information. Of the 244 student attendees, $24 \%$ participated in the study. Figures 1 - 6 depict demographics for those who participated in the study.

Table 1. Forum Attendee Information

\begin{tabular}{|c|c|c|c|c|}
\hline Level of Learner & Course Number & Course Name & Program/Discipline & $\begin{array}{c}\text { Number of } \\
\text { Participants }\end{array}$ \\
\hline $\begin{array}{c}\text { Graduate } \\
\text { Year 2 of 3 }\end{array}$ & PT 725 & Professional Issues II & Doctor of Physical Therapy & 40 \\
\hline $\begin{array}{c}\text { Graduate } \\
\text { Year 1 of 3 }\end{array}$ & PT 651 & Professional Socialization II & Doctor of Physical Therapy & 42 \\
\hline $\begin{array}{c}\text { Graduate } \\
\text { Year 1 of 2 }\end{array}$ & PAS 510 & $\begin{array}{c}\text { Evidence-Based Medicine and } \\
\text { Population Health }\end{array}$ & Physician Assistant Studies & 32 \\
\hline $\begin{array}{c}\text { Graduate } \\
\text { Year 2 of 3 }\end{array}$ & NUR 804 & Global Healthcare Policy & Nursing (DNP) & 8 \\
\hline $\begin{array}{c}\text { Graduate } \\
\text { Semester 3 of 4 }\end{array}$ & NUR 505 & $\begin{array}{c}\text { Evidence-Based Primary } \\
\text { Healthcare - Nursing with Children } \\
\text { \& Families }\end{array}$ & Nursing (MSN) & 20 \\
\hline $\begin{array}{c}\text { Undergraduate } \\
\text { Year 4 of 4 }\end{array}$ & NUR 421 & $\begin{array}{c}\text { Professional Nursing and the } \\
\text { Common Good }\end{array}$ & Nursing (BSN) & 20 \\
\hline $\begin{array}{c}\text { Undergraduate } \\
\text { Year 2 of 4 }\end{array}$ & NUR 220 & $\begin{array}{c}\text { Medical-Surgical Nursing I } \\
\text { Common/Chronic Conditions }\end{array}$ & Nursing (BSN) & 9 \\
\hline $\begin{array}{c}\text { Undergraduate } \\
\text { Year 1 of 4 }\end{array}$ & NUR 100 & Health Promotion & Nursing (BSN) & 2 \\
\hline $\begin{array}{c}\text { Undergraduate } \\
\text { Year 3 of 4 }\end{array}$ & HLT 360 & Human Nutrition & Health and Wellness & 10 \\
\hline $\begin{array}{c}\text { Undergraduate } \\
\text { Year 3 of 4 }\end{array}$ & HLT330 & $\begin{array}{c}\text { Health and Wellness Promotion } \\
\text { and Programming }\end{array}$ & Health and Wellness & 8 \\
\hline $\begin{array}{c}\text { Undergraduate } \\
\text { Year 4 of 4 }\end{array}$ & Clinical Perspectives VI & Athletic Training & 9 \\
\hline
\end{tabular}




\begin{tabular}{|c|c|c|c|c|}
\hline $\begin{array}{c}\text { Undergraduate } \\
\text { Year 2 of 4 }\end{array}$ & JCG 256 & Justice and the Common Good & $\begin{array}{c}\text { Various Undergraduate } \\
\text { Programs }\end{array}$ & 12 \\
\hline $\begin{array}{c}\text { Undergraduate } \\
\text { Year 1 of 4 }\end{array}$ & REL 100 & Introduction to Christianity & $\begin{array}{c}\text { Various Undergraduate } \\
\text { Programs }\end{array}$ & 32 \\
\hline & Community Member & N/a & N/a & 11 \\
\hline & Total Attendees & & & $\mathbf{2 5 5}$ \\
\hline
\end{tabular}

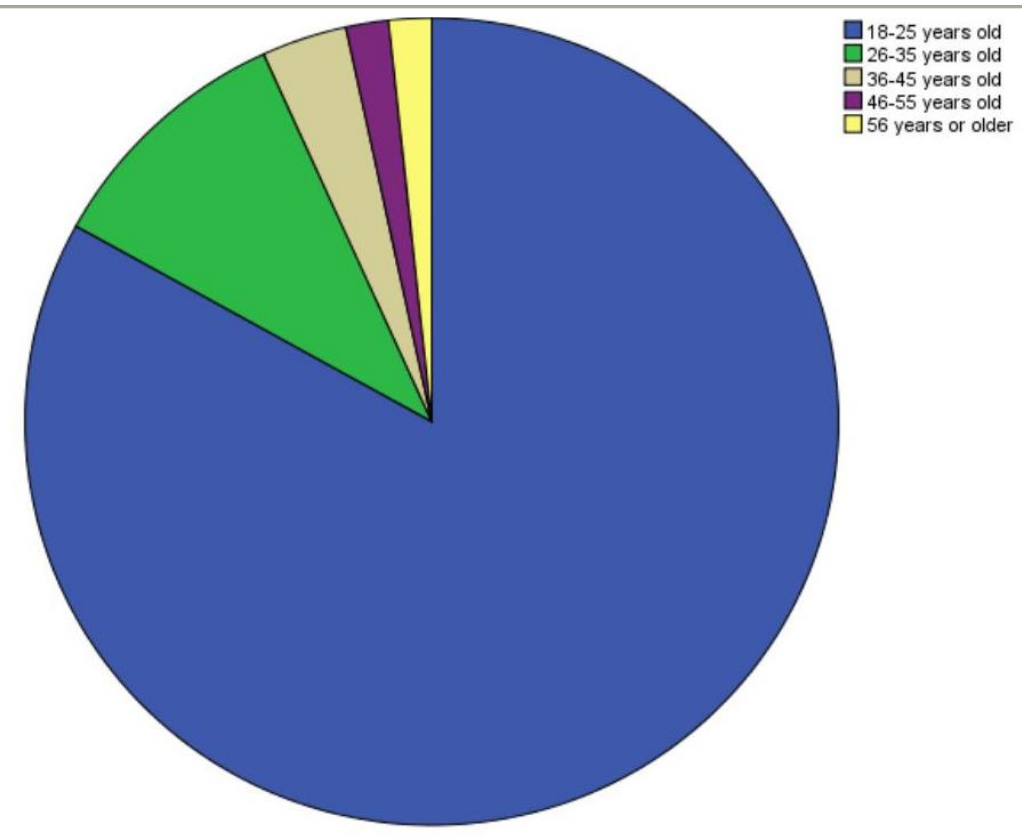

Figure 1. Age of Participants

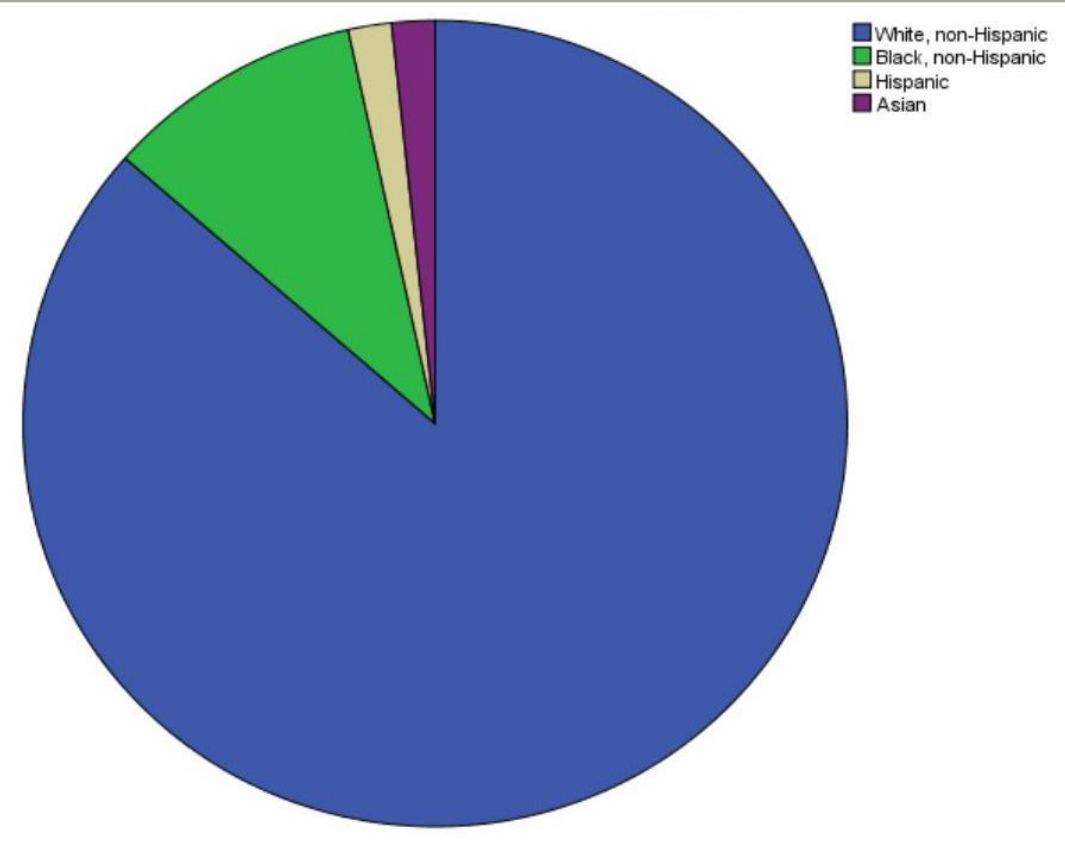

Figure 2. Participant Race/Ethnicity 


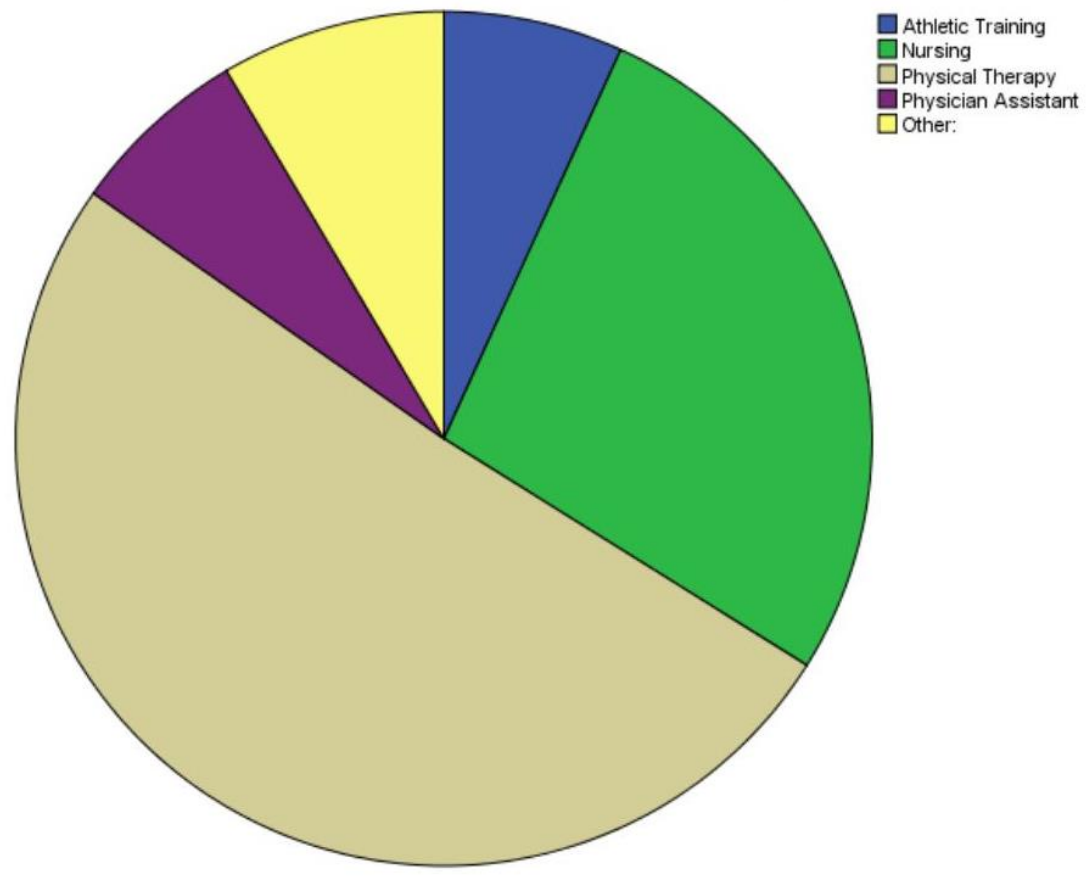

Figure 3. Discipline - Selected Choice

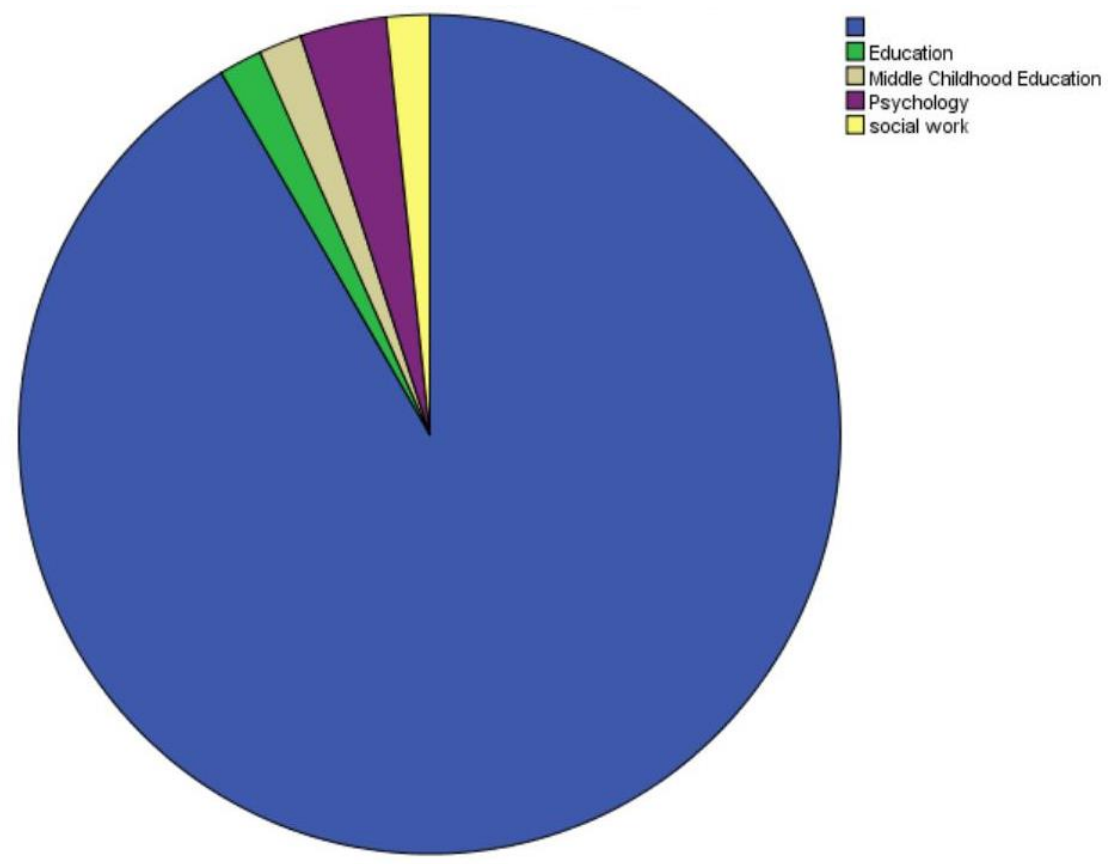

Figure 4. Discipline Other 


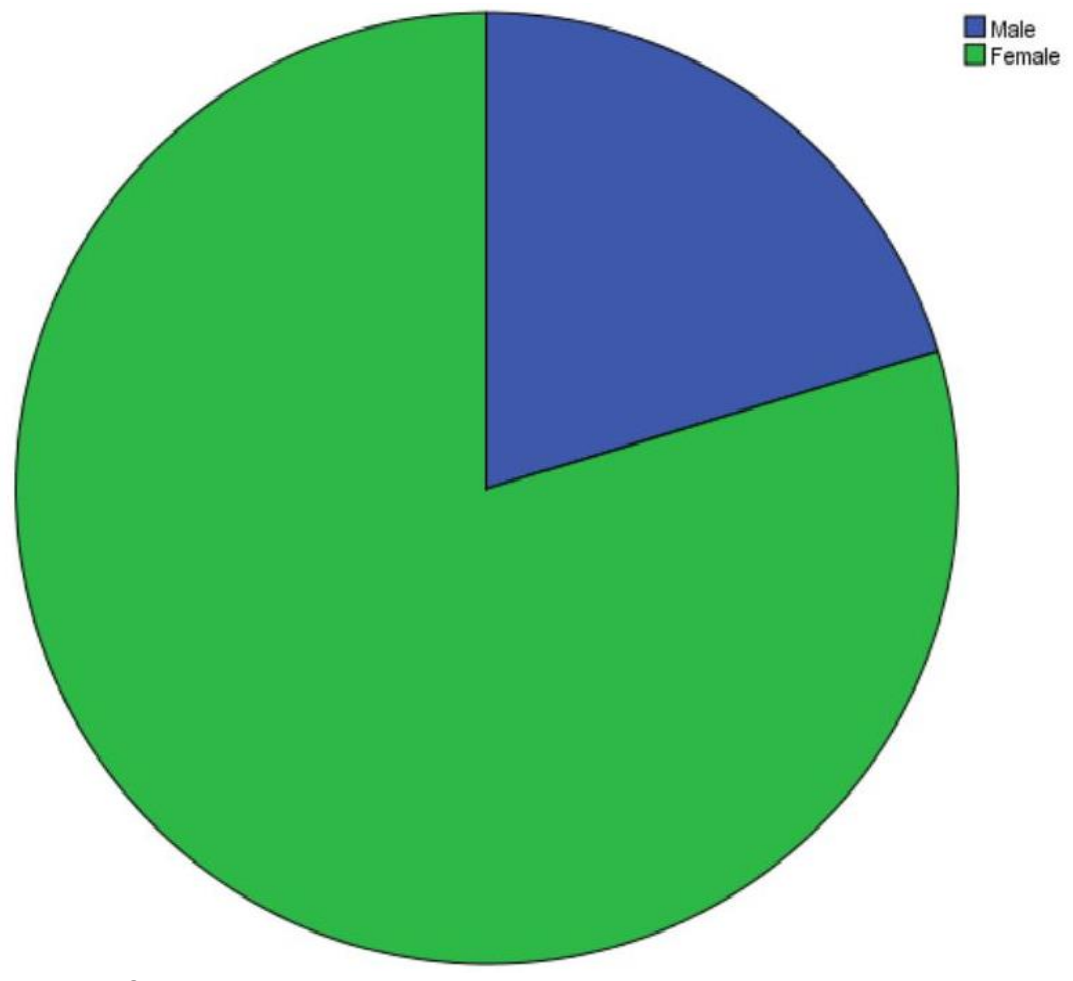

Figure 5. Gender

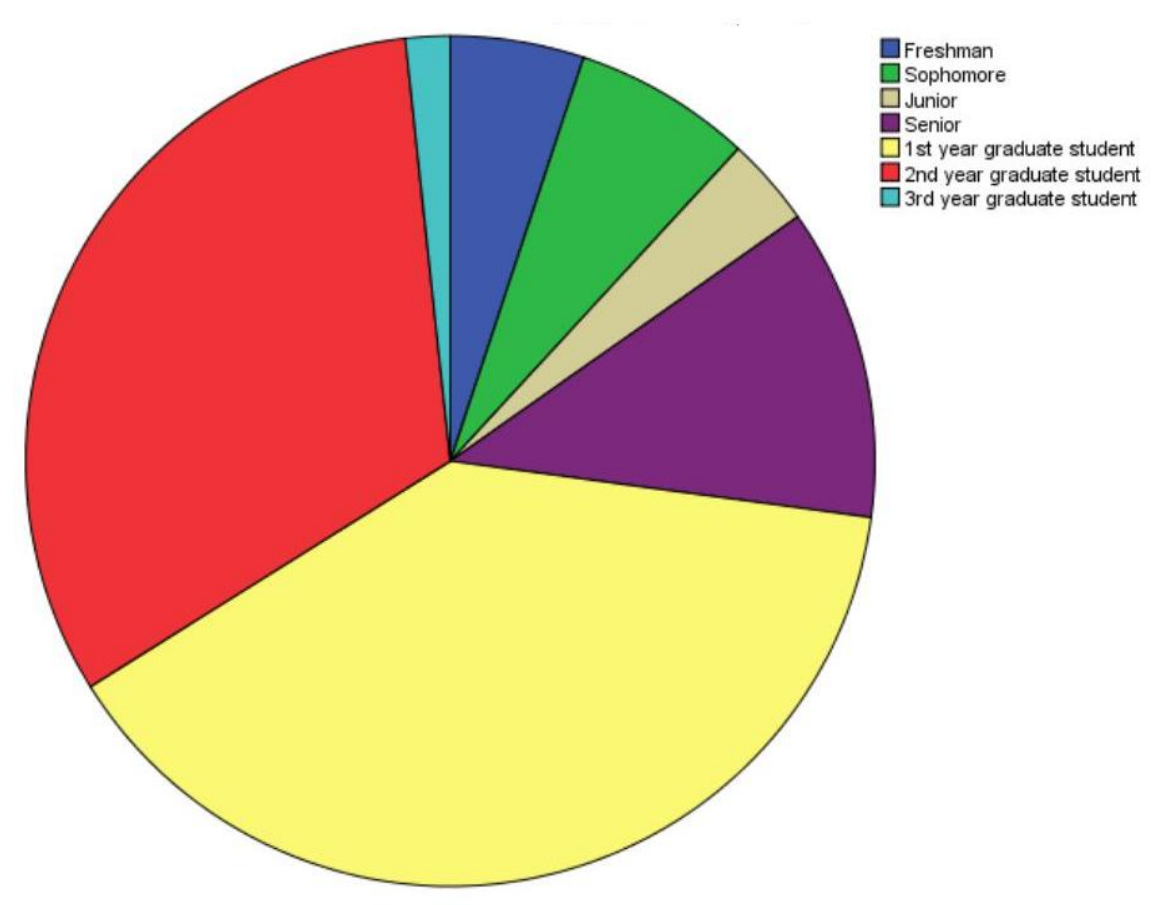

Figure 6. Year in Your Academic Program 


\section{Logistics of The Greater Cincinnati Quality of Life Forum Event}

Recruitment for the no-cost event was sent to clinical and community partners, the Mount campus community, and local government leaders. Principal investigators acquired University Internal Review Board (IRB) approval to conduct the research study. Attendees registered through an online reservation platform through the Mount Quality of Life Forum page. All attendees completed pre-course readings and video viewings, as part of required coursework, to enhance their understanding of the SDoH and HD plaguing the Greater Cincinnati area. Among these readings were excerpts from the Robert Wood Johnson Foundation, IPEC, The International Classification of Functioning, Disability, and Health, The State of Black Cincinnati 2015: Two Cities, and Addressing Social Determinants of Health and Health Disparities. $2,8,3,15,16$ Faculty underwent training to facilitate small group discussions that occurred during the evening's events.

\section{Data Collection and Recruitment Methods}

Data was collected utilizing Qualtrics, LLC Research Suite for this study. The principal investigators developed five demographic questions and five open-ended reflection questions. An employee in the Office of Institutional Research, who functioned as a research assistant, created the Qualtrics link. Refer to Appendix 1 for the survey.

Following the event, the research assistant solicited student participants via email. Participants who consented completed an electronic survey. The research assistant provided the primary investigators with the de-identified data set after a two-week collection window. At no time during the study were the primary investigators privy to or had access to the original data set as only the research assistant has an approved institutional license to access Qualtrics.

The primary investigators' research assistant used student email addresses for the sole purpose of requesting student participation in the Forum survey. Email addresses were used for a single survey effort. If during the study a student did not respond to the survey request, the research assistant sent a one-time survey reminder email message after one week.

During data collection, email addresses were stored on a secure network drive. The file containing student email addresses was uploaded into Qualtrics, LLC Research Suite software. The data provided to the primary investigators were de-identified, thereby maintaining respondent anonymity.

\section{Data Set / Analysis}

Qualitative analysis of students' written survey reflections included an inductive analysis of the text for emergent themes and coding by investigators. In order to achieve trustworthiness, coding teams compared themes and identification of relevant text. Two independent researchers utilized a directed content analysis via a color-coding scheme. Table 2 presents samples of the coding schematic. Multiple disciplines support a directed content analysis when conducting qualitative research. ${ }^{17}$ This approach includes systematically analyzing manifest and latent content including coding, categorical separation, and thematic abstraction. After completion of the individual thematic analyses, the researchers met periodically to review commonalities and refine the coding process within and across the data. This process of validation supports thematic integrity. ${ }^{18}$ Quantitative data were analyzed using IBM SPSS Statistics for Windows, Version 22.0 (IBM Corp., Armonk, NY). Descriptive statistics were conducted on the sample of survey respondents.

Table 2 Samples of Coding Schematics

\begin{tabular}{|l|l|l|}
\hline \multicolumn{1}{|c|}{ Meaning Unit (Text being Analyzed) } & \multicolumn{1}{|c|}{$\begin{array}{c}\text { Condensed Meaning Unit } \\
\text { (shortening, while still } \\
\text { preserving the core) }\end{array}$} & Code (Abstraction) \\
\hline $\begin{array}{l}\text { "Widened my view and understanding of health } \\
\text { disparities" }\end{array}$ & Widened view of health disparities & Raised awareness \\
\hline $\begin{array}{l}\text { "The various concentrations that were assigned in } \\
\text { the same group contributed different factors to } \\
\text { solving these disparities and how they treat them" }\end{array}$ & $\begin{array}{l}\text { Various concentrations contributed } \\
\text { different factors to solving these } \\
\text { disparities }\end{array}$ & $\begin{array}{l}\text { Diversified approach to } \\
\text { patient }\end{array}$ \\
\hline $\begin{array}{l}\text { "Content is already discussed in depth in the } \\
\text { community portion of the nursing curriculum" }\end{array}$ & $\begin{array}{l}\text { Content is already discussed } \\
\text { previously in coursework }\end{array}$ & $\begin{array}{l}\text { Redundant of previously } \\
\text { learned information }\end{array}$ \\
\hline $\begin{array}{l}\text { "Treating all fairly and providing the same level of } \\
\text { care to all. These [prof. code of ethics] would allow } \\
\text { us to make sure that people are not receiving worse } \\
\text { healthcare due to their class or race" }\end{array}$ & $\begin{array}{l}\text { Treating all patients fairly is } \\
\text { professionally ethical }\end{array}$ & $\begin{array}{l}\text { Justice within patient } \\
\text { care }\end{array}$ \\
\hline
\end{tabular}




\section{RESULTS}

Four major themes evolved as presented in Tables 3-6

Table 3. Theme 1

\begin{tabular}{|l|l|}
\hline Category: Consciousness & $\begin{array}{l}\text { Theme: IPE activity allowed learners to recognize what they } \\
\text { didn't or did know/understand about health disparities and/or } \\
\text { social determinants of health } \\
\text { Example Text }\end{array}$ \\
\hline Raised awareness & $\begin{array}{l}\text { "My perception was shifted by realizing the severity of the } \\
\text { problem. I did not know how bad some of the neighborhoods } \\
\text { were in the area". }\end{array}$ \\
\hline Knowledge recognition & "Made me recognize what I already knew". \\
\hline Knowledge expansion & $\begin{array}{l}\text { "Made me think of ways that I could impact this issue now } \\
\text { and in the future as a practicing clinician". }\end{array}$ \\
\hline
\end{tabular}

Table 4. Theme 2

\begin{tabular}{|l|l|}
\hline Category: Roles and responsibilities impact patient care & $\begin{array}{l}\text { Theme: IPE activity allowed for learners to recognize and } \\
\text { appreciate the impact their own and others' discipline } \\
\text { roles/responsibilities have on patient outcomes } \\
\text { Example Text }\end{array}$ \\
\hline Raised awareness of other disciplines & $\begin{array}{l}\text { Allowed for me to see the views of other disciplines on this } \\
\text { issue which helped to solidify my own personal views. }\end{array}$ \\
\hline Knowledge expansion of other disciplines & $\begin{array}{l}\text { Furthered my knowledge on the scope of practice of other } \\
\text { professions. }\end{array}$ \\
\hline Knowledge recognition regarding own discipline & $\begin{array}{l}\text { I more accurately know my role as a team member helping a } \\
\text { member of the community }\end{array}$ \\
\hline Diversified approach to patient & $\begin{array}{l}\text { Made me realize the value of working as part of a healthcare } \\
\text { team and not individually, and the impact this has on the } \\
\text { patient. }\end{array}$ \\
\hline
\end{tabular}

Table 5. Theme 3

\begin{tabular}{|l|l|}
\hline $\begin{array}{l}\text { Category: Professional values and ethics impact } \\
\text { practice }\end{array}$ & $\begin{array}{l}\text { Theme: IPE activity influenced learners to reflect on their } \\
\text { professional code of ethics that calls them to provide and } \\
\text { advocate for patient care that is: holistic, equitable, universal, } \\
\text { and extends into communities. } \\
\text { Example Text }\end{array}$ \\
\hline Justice within patient care & $\begin{array}{l}\text { "Treating all fairly and providing the same level of care to all. } \\
\text { These [prof. codes of ethics] would allow us to make sure } \\
\text { that people are not receiving worse healthcare due to their } \\
\text { class or race". }\end{array}$ \\
\hline Universal healthcare & "Each and every person deserves care". \\
\hline Holistic and non-judgmental care to all & $\begin{array}{l}\text { "Importance of considering all factors with which a patient } \\
\text { presents". }\end{array}$ \\
\hline Advocating for patients & $\begin{array}{l}\text { "This can guide me in addressing the health disparity } \\
\text { because if I advocate for the patient to get them the best } \\
\text { care possible". } \\
\text { "I want to have a list of outreach programs to help patients as } \\
\text { well as be a part of outreach community for people who do } \\
\text { not know where to go". }\end{array}$ \\
\hline Advocating beyond the bedside, into community &
\end{tabular}


Table 6. Theme 4

\begin{tabular}{|l|l|}
\hline \multicolumn{1}{|c|}{ Category: IPE activity [Forum] not impactful on practice } & $\begin{array}{l}\text { Theme: IPE activity did not impact all learners due to: self- } \\
\text { perception as "higher-level" learner, desire to hear/discuss } \\
\text { bilateral analysis of topic, or lack of IPE/IPEC "buy-in": } \\
\text { Example Text }\end{array}$ \\
\hline Redundant of previously learned information & $\begin{array}{l}\text { "Didn't have much impact, knew most of the information } \\
\text { talked about". }\end{array}$ \\
\hline $\begin{array}{l}\text { Unable to relate IPE activity to IPEC competencies: Values } \\
\text { and Ethics }\end{array}$ & $\begin{array}{l}\text { "Group discussions were a complete waste of time and didn't } \\
\text { even relate to the case". }\end{array}$ \\
\hline Not all viewpoints (counterarguments) presented at the forum & $\begin{array}{l}\text { "Didn't facilitate my learning because it was very one-sided } \\
\text { and was politically biased (far left and liberal)". }\end{array}$ \\
\hline Unable to relate IPE activity to IPE (WHO, 2010) definition & $\begin{array}{l}\text { "Being in groups was awkward, would learn more discussing } \\
\text { in class with other PT students". }\end{array}$ \\
\hline Too low-level [Bloom's taxonomy] for learner & $\begin{array}{l}\text { "Pre-reading and listening to speakers is not as effective a } \\
\text { teaching method as first-person experience working with the } \\
\text { populations in question". }\end{array}$ \\
\hline $\begin{array}{l}\text { Unable to relate the value of IPE to personal career } \\
\text { competence }\end{array}$ & "I'Ill worry about quality of life when I pass grad school". \\
\hline
\end{tabular}

\section{DISCUSSION}

\section{Relationship of Results to Framework, Aims, and Objectives}

This learning activity aimed to engage interprofessional students and attendees on the effect of health disparities on quality of life. Additional objectives included raising learner awareness, expanding knowledge, and recognizing that interprofessional care supports a holistic approach to patients' diverse needs. There is also a message presented in Themes 3 and 4 addressing a unique desire for higher-level action-orientated IPE activities, such as direct patient care and real-time advocacy opportunities. When designing IPE learning activities, careful alignment of the activity to the learner audience allows for full integration of IPE as a process, rather than a one-time event that serves to meet all IPE learning outcomes. ${ }^{19}$

Analysis of the data revealed three learner categories, which have been identified as The Novice Learner, The Experienced Learner, and the Skeptical Learner as seen in Figure 6.

The novice learner. The novice learner is one who has a desire to know and notes the IPE activity as allowing them to raise awareness and expand knowledge surrounding interprofessional care and health disparities [the given IPE activity topic]. The novice learner also expands on how IPE allows for self-understanding of his/her professional role within the interprofessional care team. The novice learner responses signify consciousness and understanding of interprofessional care and health disparities.

The experienced learner. The experienced learner is one who has a desire to act upon previously gained knowledge and/or experience. It is important to note that the experienced learner is not always one who is an upperclassman within their academic program. Rather, the experienced learner possesses prior knowledge, skills, or life experience surrounding the given IPE topic(s). That prior knowledge/experience coupled with the IPE activity manifests as a variety of phenomena. Some experienced learner participants expressed heightened motivation after the IPE activity to use the experience as a springboard for improving their IPE performance in the clinical setting.

The experienced learner expressed that the IPE activity allowed them to recognize and appreciate the impact their own and others' discipline roles and responsibilities have on patient outcomes. They also expressed how their discipline's professional Code of Ethics allows them "to make sure that people are not receiving worse healthcare due to their class or race." This expression is in line with the IPEC Core Competencies (2016) and the IHI Triple Aim (2008), with the patient at the center of the care. Without the patient at the center of the care, we would be taking away from "our highest priority." $8,5,20$

The skeptical learner. The skeptical learner is one who questions the value and validity of interprofessional practice (IPP), IPE and/or IPE learning activities. Like the experienced learner, the skeptical learner is not always one who is an underclassman within their academic program; some data reveals quite the opposite. Rather, it is a learner who may be new to IPP and/or IPE or even one who feels all viewpoints should be presented equally surrounding a given topic, in this case, health disparities. The skeptical 
learner expressed the IPE activity as 'not having much impact', a "complete waste of time", or not as effective as "first-person experience working with the populations in question".

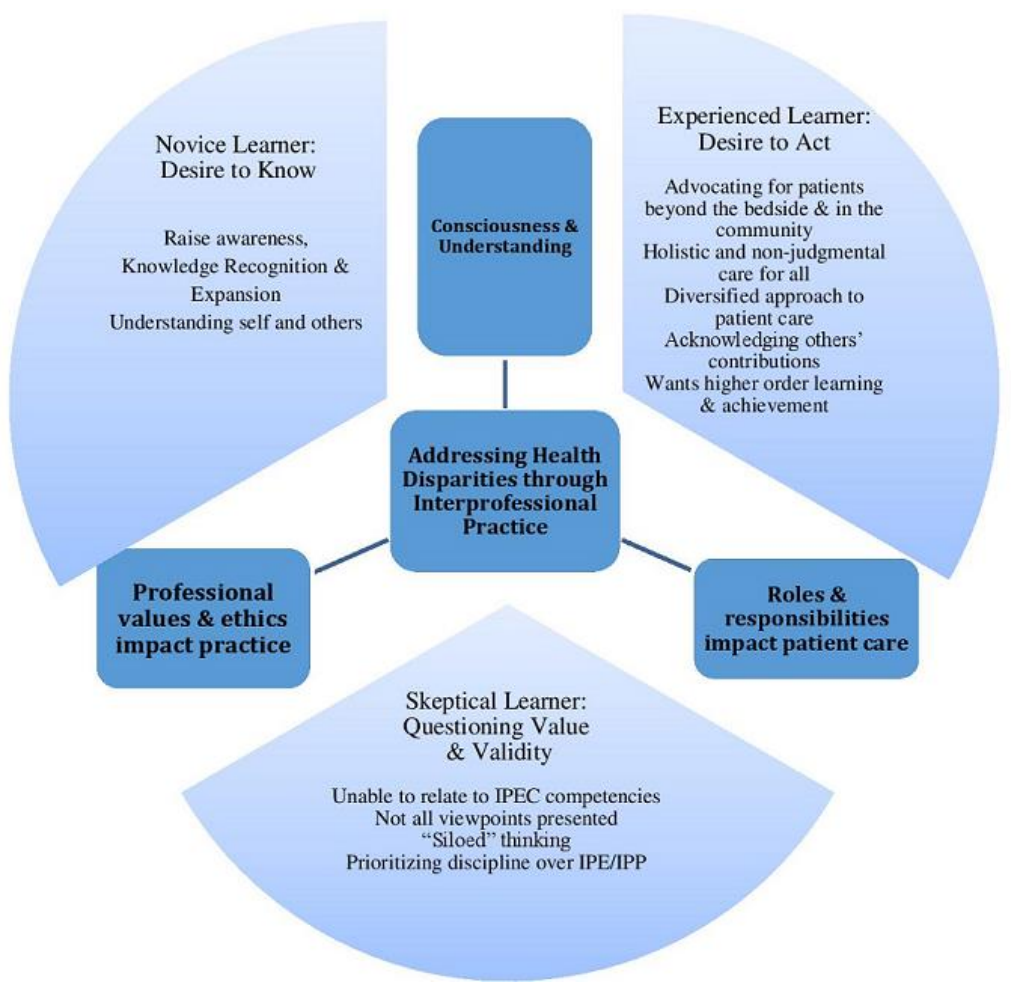

Figure 6. Learner Categories

\section{STRENGTHS AND LIMITATIONS}

The strengths of this study include the broad disciplines represented, including undergraduate and graduate learners, licensed professionals, and community organizations. Personal experiences contributed to the event by providing unique perspectives on the issues impacting the quality of life. The intentionally crafted IPE small groups, which included diverse disciplines, facilitated interprofessional learning and communication. The results extracted from this study emphasize the need to be cognizant and to adapt to the various stages of learner present within professional and non-professional programs.

The most significant limitation of this study came from the non-mandatory nature of the post-event survey. As a result, the response rate was low considering the number of participants. Additionally, an electronic open-ended survey does not allow participants to engage in a robust discussion. Perhaps having post-event debriefings or focus groups would capture richer data. Another limitation identified was limited attendance expectation from faculty outside of the School of Health Sciences. As a result, a limited number of students from non-health science professions attended the 2018 Forum.

\section{RECOMMENDATIONS FOR FURTHER RESEARCH}

This research has provided the foundational learner perspectives needed to embark on structured IPE curricula with embedded learning activities. Opportunities for further study include the effect IPE activities may have on curricular revisions, IPE School initiatives, quantitative studies focusing on longitudinal achievement of IPEC competencies, and ultimately the impact of IPE curricula on patient health outcomes. Understanding learners at the outset of an academic program may allow for better integration of IPE activities in appropriate courses and time intervals. Further, this research has not addressed those seeking action-oriented IPE activities. This must be addressed for experienced learners.

The skeptical learners' responses, at first glance, appear indifferent to the IPE activity and perhaps, the IPEC Core Competencies. Given the participants are pre-licensure learners, inherently the focus must be on how IPE can be improved in our academic setting, and thus, translate into professional practice. These responses must be taken with reservation. Therefore, future IPE 
endeavors must address the need to embed IPE into earlier phases of curricula, individual perspectives on the value of IPE, improvement on the intentionality and delivery of IPE initiatives, and practical application of IPE within current healthcare teams.

Recognizing the variability in students' understanding of interprofessional practice, curricula should include evidence supporting the IPEC Core Competencies to ideally enhance health outcomes. Educators could benefit from identifying gaps in the literature related to IPE and student perceptions. As an ongoing initiative within the School of Health Sciences, principal investigators identify the need to continue longitudinal assessment of students' development through interprofessional education activities.

\section{CONCLUSION}

The Quality of Life Forum held at the Mount was effective at utilizing the IPEC core competencies to raise learner awareness of $\mathrm{HD}$ in the local community and how SDoH play a role in the ability to deliver quality healthcare within an inter-professional team. Although there were limitations in the study, our university has made this a recurring annual event and will address the opioid epidemic as it specifically relates to the Greater Cincinnati area in 2019.

Future goals include offering IPE initiatives throughout the health sciences professional curricula via simulations, community-based initiatives, and modules or e-learning. Implementing specific "next steps" for students following subsequent forums to guide them into implementing IPE into clinical practice has been considered. As students become more familiar with IPE initiatives in the health science professional curricula and integrate these into their daily clinical practice, ideally we will see a more team-based approach to patient-centered care.

\section{REFERENCES}

1. Lash DB, Barnett MJ, Parekh N, Shieh A, Louie MC, Tang TT. Perceived benefits and challenges of interprofessional education based on a multidisciplinary faculty member survey. Am J Pharm Educ. Dec 15 2014;78(10):180.

2. Foundation RWJ, Carger E, Westen D. A New Way to Talk About the Social Determnants of Health2010. Located at: Vulnerable Populations Portfolio, Robert Wood Johnson Foundation; https://www.rwif.org/en/library/research/2010/01/a-new-way-to-talk-about-the-social-determinants-of-health.html. Accessed December 12, 2019.

3. Organization WH. International Classification of Functioning Disability and Health (ICF). Classification 2018; http://www.who.int/classifications/icf/en/. Accessed March 10, 2018.

4. Lash DB, Barnett MJ, Parekh N, Shieh A, Louie MC, Tang TTL. Perceived benefits and challenges of interprofessional education based on a multidisciplinary faculty member survey. Am J Pharm Edu. 2014;78(10):180-180.

5. Brooks K. The IHI Triple Aim. Initiatives 2018; http://www.hhi.org/Engage//nitiatives/TripleAim/Pages/default.aspx. Accessed March 10, 2018.

6. Zorek J, Raehl C. Interprofessional education accreditation standards in the USA: a comparative analysis. J Interprof Care. Mar 2013;27(2):123-130.

7. Summit loMUCotHPE. Health Professions Education: A Bridge to Quality. In: Greiner AC, Knebel E, eds. Washington DC: National Academies Press; 2003: https://http://www.ncbi.nlm.nih.gov/books/NBK221528/.

8. Collaborative IE. Core competencies for interprofessional collaborative practice: 2016 update. Washington, DC: Interprofessional Education Collaborative;2016.

9. Illingworth P, Chelvanayagam S. The benefits of interprofessional education 10 years on. Br J Nurs. Jul 27 2017;26(14):813-818.

10. Panel IECE. Core competencies for interprofessional collaborative practice: Report of an expert panel. 2011. Located at: Interprofessional Education Collaborative, Washington DC.

11. Long S, Schwartz BW, Conner-Kerr T, Cada EA, Hogan R. Priorities, strategies, and accountability measures in interprofessional education. J Allied Health. Aug 2014;43(3):e37-44.

12. Markey K, Barnes C. Promoting partnership working for undergraduate students. Br J Nurs. 2009;18(11):677-684.

13. Michalec B, Giordano C, Pugh B, Arenson C, Speakman E. Health Professions Students' Perceptions of Their IPE Program. J Allied Health. Spring2017 2017;46(1):10-20.

14. Bureau UC. Quick Facts: Cincinnati city, Ohio. 2018; https://http://www.census.gov/quickfacts/fact/table/cincinnaticityohio/PST045216. Accessed March 11, 2018.

15. Jones Baker D. The State of Black Cincinnati 2015: Two Citites2015, Urban League of Greater Southwestern Ohio.

16. Adler N, Cutler D, Fielding J, et al. Addressing Social Determinants of Health and Health Disparities. A vital direction for helath and health care. Washington DC: National Academy of Medicine; 2016. 
17. Graneheim UH, Lundman B. Qualitative content analysis in nursing research: concepts, procedures and measures to achieve trustworthiness. Nurse Educ Today. Feb 2004;24(2):105-112.

18. Polit DF, Beck CT. Nursing Research: Generating and Assessing Evidence for Nursing Practice. 10th ed. Philadelphia, PA: Wolters Kluwer Health; 2017.

19. Olson R, Bialocerkowski A. Interprofessional education in allied health: a systematic review. Med Educ. Mar 2014;48(3):236-246.

20. Feeley, D. The Triple Aim or the Quadruple Aim? Four Points to Help Set Your Strategy. Institute for Healthcare Improvement Blog. Available at: http://www.ihi.org/communities/blogs/the-triple-aim-or-the-quadruple-aim-four-pointsto-help-set-your-strategy. Published November 28, 2017. Accessed March 11, 2018.

\section{APPENDIX 1}

Quality of Life Forum Post Event Survey Questions

Informed Consent:

"The purpose of the study is to ascertain what impact The Greater Cincinnati Quality of Life Forum has on student perception of health disparities and social determinants of health during the annual forum as well as how the event facilitates student learning about such issues affecting the community and/or healthcare.

Participants are asked to complete an online survey, using the Qualtrics, LLC Research Suite, one-time following the 2018 Quality of Life Forum. Completion of the survey can be done all at once or over a short period of time. Responses are submitted through the Qualtrics, LLC Research Suite software and are not linked to your academic record or course grade. Data will be collected and de-identified by a research assistant from Institutional Research at Mount St. Joseph University prior to being analyzed by the School of Health Sciences primary investigators. The survey, consisting of de-identifiable demographic information and four open-ended questions, will be analyzed for trends and themes related to student perception about the Quality of Life Forum and how the event may impact their role within the community and/or healthcare as it relates to health disparities and social determinants of health.

Participation in this study is voluntary. Refusal to participate or discontinuation of participation will involve no penalty or loss of benefits to which you are otherwise entitled. By completing this survey, you indicate your consent to participate in this study." Demographic Information

1.) Participant age:

$\begin{array}{ll}0 & 18-25 \text { years old } \\ 0 & 26-35 \text { years old } \\ 0 & 36-45 \text { years old } \\ 0 & 46-55 \text { years old } \\ 0 & 56 \text { years old or older }\end{array}$

2.) Participant gender:

$0 \quad$ Male

- Female

3.) Participant race:

$\begin{array}{ll}0 & \text { White, non-Hispanic } \\ 0 & \text { Black, non-Hispanic } \\ 0 & \text { Hispanic } \\ 0 & \text { American Indian or Alaska Native } \\ 0 & \text { Asian } \\ 0 & \text { Native Hawaiian or Other Pacific Islander }\end{array}$

4.) Discipline:

$\begin{array}{ll}0 & \text { Athletic training } \\ 0 & \text { Health and Wellness } \\ 0 & \text { Nursing } \\ 0 & \text { Physical Therapy } \\ 0 & \text { Physician Assistant } \\ 0 & \text { Other }\end{array}$

Reflection Questions 
1.) What aspect of the Quality of Life Forum impacted your perception about health disparities and social determinants of health within in the local community?

2.) What aspect of the Quality of Life Forum facilitated your learning about health disparities and social determinants of health within in the local community?

3.) Think about a time where you may have felt uncomfortable by someone's presence. Can you identify your bias toward a particular identity-is it a racial bias? A class bias? An ability bias? Etc.

4.) Think back to your conversations during the Quality of Life Forum. Provide examples from your professional code of ethics which facilitated your discussion. Discuss how these values will guide you in addressing health disparity in interprofessional practice.

5.) Change leadership is "the ability to influence and enthuse others through personal advocacy, vision, and drive, and to access resources to build a solid platform for change."1(p9) How will this Quality of Life Forum experience make you a change leader in the community?

**Higgs M, Rowland D. Building change leadership capability: 'The quest for change competence'. J Change Manag. 2000;1:116-130 